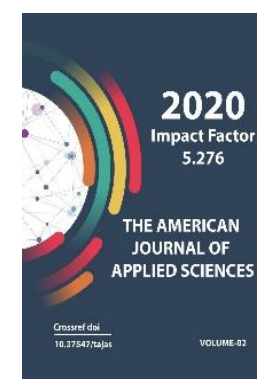

\title{
Sources, Ways And Methods Of Distribution Of Gallow Nematodes On Vegetable Crops In Surkhandarya Region
}

\section{Karim Eshnazarov}

Termez State University, Uzbekistan

Copyright: Original

content from this work

may be used under the

terms of the creative

commons attributes

4.0 licence.

\section{ABSTRACT}

The article provides information on the way of dispersal, methods of distribution and harmfulness of root-knot nematodes on vegetable crops of the Surkhandarya region.

\section{KEYWORDS}

Phytonematodes, melodyynosis, root knot nematodes, distribution, active, passive, harmfulness, tomato, vegetable crops.

\section{INTRODUCTION}

T Among the pests and diseases of plants, one of the main places is occupied by phytonematodes, which cause enormous economic damage to agriculture, expressed in a significant decrease in yield. Among the most dangerous diseases of vegetable crops is melodyynosis caused by root gall nematodes.
Especially when developing a system for protecting vegetable crops from root gall nematodes will determine the focus on the spread of the source. 


\section{MATERIAL AND METHODS}

To clarify the phytohelminthological status, studies were carried out in agricultural farms of the Surkhandarya region. To identify phytonematodes, the selection of soil and plant samples was performed by the route method $[2,5]$.

To isolate nematodes from soil and plant organs, a modified Berman funnel method was used and fixed with a $4 \%$ formalin solution. Enlightenment of nematodes was carried out in a mixture of glycerol with alcohol (1: 3), and permanent preparations on glycerol were prepared for in-office processing of the material according to the Sainhorst method [8].

\section{RESULTS AND DISCUSSION}

For the emergence and development of foci of melodydenosis of vegetable crops, the source is plant roots affected by gall nematodes and contaminated soil. The causative agent of melodygynosis is invasive larvae.

The mechanism of transmission of the pathogen is certain pathways of movement from the sources of the pathogen to healthy susceptible plants, which leads to the emergence of new foci of infection.

Gall nematodes in nature spread actively and passively. Active distribution is associated with the movement of invasive larvae in the soil in search of a host plant $[1 ; 4$.$] .$

As our observations on vegetable crops affected by melodyynosis show, invasive larvae can migrate from plant roots into the soil, or vice versa, from the infected soil, they penetrate into the plant root tissue. There are also overcharged neighboring plants, which thus creates the prerequisites for the emergence of secondary foci, which often merge together, forming a vast array of lesions.
Gallic non-methods spread to large plants passively, ie mechanically: by wind (anemochoria), water (hydrochoria), soil (edaphochoria), animals (zoochoria) and, in most cases, by humans $[3 ; 4$.$] .$

The greatest danger is the spread of root-knot nematodes with infected seedlings. In this regard, it is necessary to take all precautions to prevent possible mechanical drift of the invasive principle into the seedling department. For considerable distances, soil particles infected with root gall nematodes are carried by the wind.

In Surkhandarya, the wind called "Afghan" blows throughout the year. It blows from the territory of Afghanistan, along the front for about $300 \mathrm{~km}$ and penetrating deep into 300$350 \mathrm{~km}$, capturing a huge area - up to 60, 3 thousand $\mathrm{km}$. The wind that has penetrated the territory of the region continues for 24-36 hours and repeats 50-60 times a year. Air masses move at a speed of $10-13 \mathrm{~m} / \mathrm{s}$, sometimes at a speed of $15-23 \mathrm{~m} / \mathrm{s}$, sometimes the wind speed reaches $25-30 \mathrm{~m} /$ $\mathrm{s}$, subjecting the soil to strong erosion, especially sandy and sandy loam. With a strong wind flow, the roots of various wild, weeds and vegetables - melons and gourds can be transported over long distances - tens of kilometers. Some of these plants are affected by gallic $M$. incognita, M. acrita, $M$. arenaria, M. javanica [6].

Under the influence of the wind, with particles of contaminated soil, mainly invasive larvae of root gall nematodes are transferred; their number varies greatly depending on the presence in a given area of foci of strong infection, or the absence of such. If the larvae enter the water, they continue to settle in such water.

In the Surkhandarya region, agricultural crops, as mentioned above, are irrigated artificially. The irrigated area is 317,700 ha. The average consumption of water per year is about 5.3 billion cubic meters of water. The irrigation 
system of the region consists of irrigation canals, inter-farm irrigation canals, with a length of $1471 \mathrm{~km}$ of on-farm irrigation canals $8284 \mathrm{~km}$. Of these, the largest irrigation canals are "Zang" - 107 km., "Sherabad" - 123 km., Irrigation system "Amu-Zang" 100.3 km., "Khazarbag" - 108 km. and "Kumkurgan" - 53 $\mathrm{km}$. These irrigation canals are connected to each other. Due to this, the flow of water entering them is mixed.

Analysis of water samples from the deepwater Amu-Darya river showed that in every 100 liters of water, up to 58 larvae of root gall nematodes were recorded. The invasive beginning got into the Amu Darya water with the runoff of the used irrigation water discharged from the plantations of cultivated plants in the Kurgan - Tyubinsk and Kulyab regions of Tajikistan. The soil and almost all vegetables - melons, industrial, subtropical and other crops of this region were heavily infected with various pathogenic organisms, especially root-knot nematodes. Studies have shown that $1 \mathrm{~m} 3$ of water flowing down from infected plantations contains from 765 to 1900 larvae of rootworm nematodes.

During irrigation rains in the mountains, mudflows eroding the soil temporarily flood agricultural lands, thereby bringing root nematodes onto them. Mudflows are repeated many times throughout the year (1020 times). Apparently, therefore, strong foci of melodydenosis were recorded in the dominant number of cases located near and along the irrigation canals.

Passive agents in the spread of root knot nematodes are people working in infected areas and agricultural people working in infected areas and farm animals.

The transfer of rootworm nematodes from field to field was facilitated by boxes, bags and other containers used to transport seedlings and other planting materials. In 100 $\mathrm{cm} 3$ of soil adhering to boxes intended for transporting tomato seedlings from greenhouses to the field, we found from 10 to 91 invasive larvae of rootworm nematodes.

In $100 \mathrm{~cm} 3$ of soil. We found in a sample from 2 to 80 invasive larvae of root-knot nematodes adhering to the shoes of workers transporting tomato seedlings from greenhouses to the field. Perhaps this is the most common and most dangerous route of mechanical transmission of rootworm nematodes from farm to farm, as well as within the farms themselves.

When analyzing the grown tomato seedlings in the Termez region and the city of Termez, cases of their strong infection were noted (41$59,6 \%$. This seedling was inhabited by root gall nematodes. As a result, for example, in other areas of the region, which subsequently caused the development of an extensive focus of melodyynosis

Gall nematodes can get to uninfected areas both with tubers and with fruits. The results of microscopic analyzes of unwashed cucumber fruits collected from crops affected by meloidinosis showed the presence of 2 to 8 larvae of root gall nematodes on their surface (by washing).

The results of our studies have shown that the spread of the infectious principle occurs during the harvesting of vegetable crops affected by melodynosis and the transportation of the harvested products. The settlement of root-knot nematodes also occurs with agricultural machinery and equipment. Microscopic analyzes of water washout from the wheels of tractors, machines and agricultural equipment showed the presence of invasive larvae of root-knot nematodes in the samples.

Manure is usually stored in an open area for a long time. Gall nematode larvae were also found in manure - from 3 to 62 larvae in 100 cm 3 samples. 
Presumably gall nematode larvae were introduced into the manure of the infected fields.

When studying the role of farm animals in the spread of nematodes, we found that the soil on the hooves of small and cattle contains larvae of gall and other nematodes. After harvesting (October - November) until the next spring (March - April) on the roles, on which foci of low-water areas were found from field to field, to the rapid dispersal of root-knot nematodes and the formation of new foci of melodyynosis.The generalization and systematization of literature data and the results of our own phytohelminthological studies give reason to believe that the pathways of the spread of foci of melodyynosis to uninfected areas of this field and to other neighboring fields are different. The dispersal of the infected beginning can occur actively and passively, Active spread is associated with the independent migration ability of the larvae of rootworm nematodes. Passive methods of settlement are: wind, irrigation water, melt water, rain flows, agricultural machinery, vehicles, shoes, clothing and human cultivation tools, containers, affected seedlings, infected tubers and root crops, manure and animals.

The ways of dispersal of gall nematodes from the source of melodyynosis are very diverse, which contributes to the possibility of their wide distribution and increase in their density in the agrobiocenosis. In such cases, the harm to agricultural crops, including the cultivation of vegetable crops, increases.

As a result of experimental work and a survey of tomato fields in the farms of the Surkhandarya region, it was found that melodyynosis on tomato is common in all surveyed farms. Southern, cotton, peanut and Javanese root knot nematodes in mixed populations have caused tomato melodyynosis, but Javanese root knot nematodes are more widespread among them. Out of the 620 hectares of tomato crops examined, $98.4 \%$ of the area was affected by meloid dynosis; everywhere, meloid dynosis had the character of epiphytotics, since the development of phytohelminthiasis reached $94-98 \%$ of the number of examined tomato plants, i.e. their landing was hit to the maximum extent. The affected plants were characterized by the death of roots, accompanied by the gradual death of the entire plant. Symptoms of the disease began to appear as early as 20-30 days after planting. On heavily affected fields, the tomato yield was low and amounted to no more than 1-2 $\mathrm{t} / \mathrm{ha}$.

To study the influence of the development of meloidoginosis on vegetable crops, in particular, on the yield of tomato plants of the Volgogradskiy 5/95 variety in field conditions, phenological observations and counts were carried out in vegetable farms. The experiment was carried out in a hospital on a specially selected mixed population of four species of root gall nematodes: $M$. incognita, M. asrita, M. arenaria, M. javanisa. The initial invasive beginning was 1800 larvae of rootknot nematodes $/ 100 \mathrm{~cm} 3$ of soil. On a plot of 1 hectare, the productivity of tomato plants was carried out. On the field, 10 plants were selected with varying degrees of damage by meloidinosis from 0 to 5 points on a five-point scale.

\section{CONCLUSION}

Thus, the results of phytohelminthological studies, the ways of spreading foci of melodyynosis are very different. Resettlement is active and passive. Active dispersal of independent migration of larvae of root gall nematodes. Passive resettlement: wind, irrigation water, melt water, rain flows, agricultural machinery, vehicles, footwear, clothing and soil, processing human tools, containers, affected seedlings, infected tubers and root crops, manure and animals. Damage to tomato by root gall nematodes, the yield decreases and significantly worsens the 
quality of products. Gall nematodes are highly harmful to vegetable crops.

\section{REFERENCES}

1. Gubina VG Ways of propagation of phytoparasitic nematodes // Phytohelminthological research. -M. 1978. -S.5-14.

2. Kiryanova E.S., Krall E.L. Plant parasitic nematodes and control measures. $\mathrm{L}$ : Nauka, 1971. T.I.-524s.

3. Mavlyanov OM Gall nematodes dangerous plant parasites. -Tashkent: Mekhnat, -1987. -96s.

4. Khurramov Sh.Kh. Ways of resettlement of phytonematodes and ways to prevent it // Byull. VIGIS. -M. 1989. - Issue 50-C. 155156.

5. Khurramov Sh.Kh., Eshnazarov K., Khurramov A.Sh. Phytohelminthology. 2020. -Termiz. 180 s.

6. Eshnazarov K. Parasitic nematodes of vegetable crops and measures to combat rootworm nematodes in the Surkhandarya region: Abstract of the thesis. Cand. biol. Science. -Tashkent, 1995. -22s.

7. Decker H. Schadliche Nematoden des Getredes und der Graser // Phytopathol. undlanzenschutz. Bd 2. - Berlin, 1974.- P. 221-237.

8. Seinhorst J. W A raipd method for the transfer of nematodes from fixative to anhydrous glycerin // Nematologica, 1959. - V.4. № 1.-P.67-69.

9. Micoletzky G. Die freilebenden ErdNematoden, mit besonderer Berucksichtigung der Steiermark under Bukowina, Zugleich mit einer Revision Samtlicher nicht mariner, freliebender Nemotoden in Farm von esenus Beschereibungen und Bestimmungs Schlusseln // Arch. Naturgesch., 1922- V. 87. $-65 \mathrm{p}$. 